\title{
THE UTILIZATION OF JIGSAW TECHNIQUE TO IMPROVE WRITING ABILITY IN TEACHING REPORT TEXT
}

\author{
Kharisma Gustiningsih $^{1}$ and Jauhar Helmie ${ }^{2}$ \\ Suryakancana University \\ Kharismagustiningsih7@gmail.com and jauharhelmie@unsur.ac.id
}

\begin{abstract}
This study was designed to improve the students' writing ability of report text by using Jigsaw technique. This study was conducted in two cycles by following the procedures of the action research. There are planning, implementing, observing, and reflecting. Each cycle consisted of two meetings. The data of the study were gathered through the following instruments, namely observation checklist, questionnaire and test. The subjects of this study were 32 students at eleventh grade of Administrasi Perkantoran (AP) program in academic year 2016-2017 of Nurulhidayah Pasundan Vocational School. The finding of the study indicated that Jigsaw technique was effective in enhancing the students' motivation and participation. From the result of questionnaire, it showed that $74 \%$ students participated actively in the first cycle and $80 \%$ students participated in the second cycle. This implied that the first criteria of success had been fulfilled. Furthermore, the finding of the study indicated that Jigsaw technique was successful in improving students' writing of report text. The improvement could be seen from the increase of students' mean writing score from 55.09 in the pre-test cycle, and 74.62 in the first cycle increase become 80.46 in the second cycle. If it calculated into class percentage, there were 4 students $(12.5 \%)$ who passed KKM in the pre-test. Meanwhile, in the cycle 1, there were 24 students $(75 \%)$ who passed KKM and it gained which was in the post-test cycle 2 there were 29 students $(90.62 \%)$ who passed KKM. So, it indicated that the second criteria of success has been achieved.
\end{abstract}

Keywords: Jigsaw technique, writing ability, teaching report text.

\section{INTRODUCTION}

People who lives in today's growth world need to learn how to write for many reasons. Considering the importance of writing in people's life especially in educational field, Indonesian government has included writing skill in the English syllabus stated in Basic Competence. Ideally, according to Basic Competence-Kompetensi Dasar (KD) of writing skill in the current Curriculum 2013, the Basic Competence of writing in 
Vocational School level is to express meaning in functional written texts and simple short essays in the form of report to interact with both the closer environment and the context of daily life.

It becomes the reason why the students have to master writing. But, there were still some difficulties faced by the students in learning writing. Based on the informal interview and writer's observation during program PLP at SMA PGRI Ciranjang. First, the students felt difficult in organizing and generating ideas. Second, the students found some serious problems when they tried to translate a native language sentence word by word into a good written foreign language. The last, they felt bored and lazy to write in class because the learning activities in writing are monotonous.

Considering the complexity of writing, especially in report text, an English teacher should be an effective teacher, who can use variety of teaching methods and strategies to improve the students' writing ability. The writing class should be facilitated with activities which motivate students to learning and comprehending that. According to Wichadee (2003), the students who do not like to speak in the large class are comfortable speaking out in a small group. So, there are a lot of methods and techniques to get the English teaching effectively. To make the teaching learning process effectively, the writer would like to propose an alternative technique which promotes cooperative and interesting activities, it is "Jigsaw Technique", in which the students are working together and sharing the ideas within the group.

Slavin (1995:122) said that jigsaw is working group or cooperative activities which are applicable in the teaching writing. In Jigsaw technique, the students work in the same group of four to six members and each member in a team becomes an expert on a topic. Group member can complete their strength and weakness in learning English because each student has a different background and ability in learning English which he or she can bring to the group. Based on the explanation above, teaching writing should encourage the student's cooperation, in expressing idea, sharing idea, asking and explaining each other in a group, so that the learning process of writing will achieve the better result especially in writing of report text or information report. That is why a new strategy or technique to improve the students' writing skill is needed to overcome the above problems. Based on the background, the researcher takes a title of this paper is "The Utilization of Jigsaw 
Technique to Improve Writing Ability in Teaching Report Text at the Eleventh Grade Students of Nurulhidayah Pasundan Vocational School in Academic Year 2016-2017’.

\title{
THEORETICAL FRAMEWORKS
}

There are some theories underpinning this research. Most of them are related to writing ability, teaching report text and Jigsaw technique.

\section{Writing}

Deporter and Hernacki (2002:179) explain that writing is a whole brain activity which uses right-brain side (emotion) and left-brain side (logic). Although right and leftbrain sides are used in writing, right-brain has a big position because it is a place which appear new ideas and emotion. All the definitions tell us that writing is activity to write something in our mind to give idea, feelings, opinion or information in writing by using pencil, pen, marker and etc in the media paper or the others.

\section{Process of Writing}

In some ways writing a paper is like driving a car. If we have ever driven in another country, we know that some rules of road may different. The rules for driving differ from country to country, the conventions for writing may change from language to language. As Blanchard (2014: 11) mention a process in involving the following steps:

\section{Step one: Prewriting}

\author{
Generating ideas, planning, and organizing our ideas \\ $\downarrow$ \\ Step two: Writing \\ Using our ideas to write a first draft \\ $\downarrow$ \\ Step three: Revising and Editing \\ Improving what we have written
}

\section{Problems of Writing}

There are many problems of teaching learning writing skill from the students. The problems come from the students' side because writing is a complex process which requires number of things, such as in using grammar correctly. This problem usually can cause some difficulties for the students in learning writing. According to Rozakis 
(2003:78-79), the most common writing errors are grammar and usage (such as wrong verb tense, and subject-verb agreement), sentences (fragments and run-ons), spelling, punctuation, capitalization, and proofreading (missing words).

\section{Report Text}

In the book of Bahasa Inggris ( Kementrian Pendidikan dan Kebudayaan, 2014 :33) proposed that an information report is a factual text that provides information about different phenomena in our life. Is is used as a way to gain better understanding of different phenomena.

\section{Generic Structures of Report Text}

One of the ways in understanding or writing a report text is by identifying the generic structures. The simple generic structure that is taught in Vocational School is divided into the three elements, namely general classification, description and conclusion.

\section{Language Features of Report Text}

The language features play significant role to assist in getting the meaning of the story. For instance, through simple present tense, it tells the readers exactly as the major feature of the story used. Therefore, all of the language features are conveyed to construct the story more alive.

\section{Jigsaw Technique}

Slavin (1995:111) says that Jigsaw includes a procedure whereby students share information they have gathered with their group mates and with the other group mate in the class. Students are quizzed on all topics and the quiz scores are averaged to form team scores. So, if the team wants to be successful, the team members must not only accomplish their subtasks but also do a good job of sharing information with their teammates.

\section{Procedure in Jigsaw Technique}

Procedure in implementing the Jigsaw technique according to Parker is: (1) Students are divided up into groups. The number in each group depends on the number of subtopics. (2) Each member of the group is assigned a section or portion of the material. (3) Each student meets with the members of the other groups who have the same assigned 
section forming an expert group. (4) The expert group learns the material together and decides on how to teach the material to the original groups. (5) Students later return to their original groups, whose members are each now an expert in one of the different areas of the topics being studied, and teach their area of expertise to the other group members. (6) A quiz is given in the end. At that time no team members may help each other .

Based on opinion above, we can conclude jigsaw is model learning technique of cooperative learning, with students learn in small group consist of four or six person, diverse inter gender ethnicity, race and ability. Cooperative in positive interdependence and responsible to present the task for each member.

\section{METHOD}

This chapter provides the research design, setting, participants, data collection, and data analysis. The research design in this study was the Classroom Action Research (CAR) which focused on a particular group of students in a certain classroom. Action research as any systematic inquiry conducted by teacher researchers, principals, and school counselors in the teaching and learning environment to gather information about how their particular school operates, how teachers teach, and how well their students learn (Mills, 2003: 1 cited in Hopkins's book, 2008: 48). The research was conducted in Nurulhidayah Pasundan Vocational School which is located at Haurwangi-Cianjur. Nurulhidayah Pasundan Vocational School is in line with the School Based Curriculum 2013. The research was held from April $10^{\text {th }}$ to May $11^{\text {th }}$ 2017. There were two cycles in this research and each cycle consisted of two meetings. The subjects of the research were 32 students at $11^{\text {th }}$ grade of Administrasi Perkantoran (AP) program in academic year 2016-2017 consisting of 32 female students as the sample. The participants were chosen, it's due to the fact that the researcher had found many problems in writing ability in that class.

In conducting the research, the researcher followed a number of steps. The steps included preliminary study to analyze and identify the problems as the preparation, followed by planning the action, implementing the action, observing, analyzing, and reflecting.

To collect the data in this research, three instruments are used. Those are observation checklist, writing test and questionnaire. Observation is used to obtain 
information concerning the activities done by the students during the teaching and learning process in the class. Then, the test used in this study is pre-test and post-test and questionnaire was a written of questions to be answered by the students.

\section{Data Analysis}

Observation, There are several categories to observe the students' response. It might be about students' behavior and students' participation during the teaching learning process in the classroom. Writing Test, According to Weigle (2002: 116), there are four aspects, there are content, organization, vocabulary and mechanic, and grammar. Then it will be specific purpose in scoring. The writer used analytical scoring rubric to analyze the data related to the students' paragraph writing test. Questionnaire, The formula to analyze data from the percentage of questionnaire result is:

$\%=\frac{n}{N} \times 100$

$\mathrm{n}=$ number of students who answered the option

$\mathrm{N}=$ number of all students in the class

\section{FINDINGS AND DISCUSSION}

This chapter discusses the description of baseline conditions (pre-test), the implementation of a class action (cycle), the results and discussion of the research. That all for answer the research question about improving of students' writing ability through jigsaw technique and students' response in implementing jigsaw technique.

\section{Finding from Classroom Action Research (CAR)}

In this part, the writer explains the data collection from tests. There were three tests, namely pre-test, post-test 1 and post-test 2 .

\section{Findings of the Pre-cycle}

A pre-cycle was conducted to get data about the factual conditions of the problems faced by the teacher and students in the teaching and learning process of writing. The precycle was conducted on April 10 ${ }^{\text {th }}, 2017$ in eleventh of AP 2 program. From that analyzing, 
it could be seen that almost of the students' writing report text was unsatisfactory. They made some mistakes such as the story has unclear information, and the ideas were unevenly organized and error grammatical. It effected that teaching learning process was not effective. The result of pre-cycle test which class average score was only 55.09. Meanwhile, English KKM score was 75. It means that students were on the serious problem. They needed a special treatment to improve their English score.

\section{Findings of the First Cycle}

Planning, The researcher was prepared lesson plan for the action. Next, the writer determined the criteria of success. The criteria of success were $75 \%$ of the students' writing score achieved the Minimum Mastery Criterion- Kriteria Ketuntasan Minimal (KKM) of English (75.0) or above and $75 \%$ of students participated in writing class. Besides, the researcher prepared the instruments for the research such as post-test 1, observation checklist, and camera to take a picture of the action. Acting, First Meeting in Cycle 1. The action of the first meeting was done on April $17^{\text {th }}, 2017$ it was follow by 32 students. It was begun by greeting to the students, checking students' attendance list, and telling the purpose of the learning material. After that, the researcher explained the material about report text. Then, before involving students in Jigsaw technique. The researcher gave a topic that about "Social Media". They described and shared the ideas based on the topic given. At the last, the researcher gave general conclusion about the material and activities that had been presented at first meeting and also explained the planning for the next meeting.

Second Meeting in Cycle 1, The action of the second meeting was done on April $20^{\text {th }}$, 2017. In the second meeting, the researcher asking of the students writing about the complete story individually. Students revised their draft on content and organization. Then students had a chance to edit their writing in terms of grammar, spelling, capitalization, and punctuation using editing guide. The final draft was the data for the post-test 1.

\section{Observing}

The researcher was monitoring during the teaching learning to notice all activities in the physical classroom activity. In the first meeting, there were $73 \%$ students who 
enthusiastically in writing report text. Then in the second meeting, there were $75 \%$ students who enthusiastically in writing report text. So, the mean result of observation checklist in the first cycle was $74 \%$ of the students were involved in writing class activity that was enthusiastic in writing report text.

\section{Reflecting}

In this phase, the researcher analyzed students' achievement and progress based on their test score got. Based on the result of the post-test 1, they were only 24 students who passed the KKM. From the data and observation, it could be seen that some students still got difficulties in writing of report text especially about one of the tenses of simple present tense. Therefore, the researcher decided that it was necessary to continue to the second cycle with doing some improvements. Findings of the Second Cycle, Planning. The second cycle was conducted on May $8^{\text {th }}$ and $11^{\text {th }}$ 2017. In this case, the writer modified the previous lesson plan based on the result of reflecting phase in the first cycle. But, in this cycle, the writer gave the topic of animal. Acting, First Meeting in Cycle 2. The action of the first meeting was done on May $8^{\text {th }}, 2017$ it was still follow by 32 students. It was begun by greeting to the students, checking students' attendance list, and telling the purpose of the learning material. After that, the researcher re-explain the material about report text last week shortly and gave material that was on language features of report text, especially about the simple present tense. Then the researcher gave a topic about "Ant" to describe by students.

Second Meeting in Cycle 2, In the second meeting, it was done on May 11 ${ }^{\text {th }}, 2017$. In this last meeting, the writer gave the students a model of a report text which added by some key words to stimulate and help students to describe the event based on the topic of ant. Then, students were asked to make the first draft (the complete story) individually and asked them to revise their draft on content and organization using the revising guide by peer correction. In the end, the students were asked to edit their writing in terms of grammar, spelling, capitalization, and punctuation using editing guide. The final draft was the data for the post-test 2. 


\section{Observing}

Then, related to the students' participation, it showed some progress than in cycle 1. The students participated well in the learning process because they are motivated to want to improve their writing ability.

The first meeting in cycle 2 , there were $78 \%$ students who enthusiastically in writing report text. Then in the second meeting, there were $83 \%$ students who enthusiastically in writing report text. So, the mean result of observation checklist in the second cycle was $80 \%$ of the students were involved in writing class activity that were enthusiastic in writing report text.

\section{Reflecting}

Based on the results of cycle 2, showed that students' progress was significant. The researcher felt satisfied because the students have significant improvement from the score they get from pre-test, post-test 1, post-test 2 and most of students gave respond actively. Furthermore, the teaching learning process was done very well and the researcher decided that the utilization of jigsaw technique in teaching report text was successful and the research could be ended.

\section{CONCLUSION}

The researcher will give the conclusion of this study, furthermore related to the conclusion, the researcher also gives some suggestion for the readers. Conclusions, After implementing Classroom Action Research at the eleventh grade students of Nurulhidayah Pasundan Vocational School and according to the result of any tests, observations and students questionnaire, it could be summarized that there was a significant difference before and after implementing jigsaw technique in writing report text. It means that implementing jigsaw technique is helpful, especially in improving students' writing of report text. It can be shown from the result of pre-test and some post-tests.

Furthermore, the students' improvement of writing report text can be seen clearly in the students' improvement score of their achievement in pre-test and two post-tests. The 
result of pre-test and post-test shown the significant improvement. The average score of pre-test was 55.09. It means there were only $12.5 \%$ of the whole students could pass the KKM. The average score of post-test 1 was 74.62 . It proved that $75 \%$ students passed KKM. The average score of post-test 2 was 80.46. Then, it was obtained that the percentage of students who could get the score above the KKM in post-test 2 was $90.62 \%$. It can be concluded that teaching report text by using jigsaw technique in the students' writing can be effectively improved.

Finally, the students' response about the utilization of Jigsaw technique was positive and it would be alternative strategy in learning writing. Therefore, Jigsaw technique could improve the students' writing ability in report text.

\section{REFERENCES}

Anas, Sudijono. 2008. Pengantar Statistika Pendidikan. Jakarta: PT. Raja Grafindo Persada.

Blanchard. K \& Root.C. 2014. Ready to Write More Second Edition. US. Longman.

Hopkins, D. 2008. A teacher's Guide to Classroom Research. Buckingham: Open University Press.

Kember, David. 2000. Action Learning and Action Research, London: Kogan Page Ltd.p.24-28

Kementrian Pendidikan dan Kebudayaan. (2014). Bahasa Inggris/Kurikulum 2013: Standar Kompetensi Mata Pelajaran Bahasa Inggris Sekolah Menengah Kejuruan. Jakarta: Pusat Kurikulum, Balitbang Depdiknas

Langan, John. 2001 College Writing Skills with Readings 5th ed, New York: McGraw Hill.

Shinoda, K and Siahaan, S. 2008. Generic Text Structure. Yogyakarta. Graha Ilmu. P.2 p 1

Slavin, R.E. 1995. Cooperative Learning : theory research and practice ( $2^{\text {nd }}$ Ed.).Boston : Alyn \& Bacon.

Aronson , E. (2000). Explore the Jigsaw Classroom. Retrieved February 15 , 2017, from http://www.jigsaw.org/tips.htm

http://idnewsenglish.blogspot.com/2016/10/improving-students-reading.html 